Article

\title{
Energy-Saving Lipid Extraction from Wet Euglena gracilis by the Low-Boiling-Point Solvent Dimethyl Ether
}

\author{
Hideki Kanda ${ }^{1,2, *}$, Peng $\mathrm{Li}^{3}$, Motonobu Goto ${ }^{1}$ and Hisao Makino ${ }^{3}$
}

1 Department of Chemical Engineering, Nagoya University, Nagoya, Aichi 464-8603, Japan; E-Mail: mgoto@ nuce.nagoya-u.ac.jp

2 Japan Science and Technology Agency, Kawaguchi, Saitama 332-0012, Japan

3 Energy Engineering Research Laboratory, Central Research Institute of Electric Power Industry, Yokosuka, Kanagawa 240-0196, Japan; E-Mails: yolipeng@ criepi.denken.or.jp (P.L.); makino@criepi.denken.or.jp (H.M.)

* Author to whom correspondence should be addressed; E-Mail: kanda@ @uce.nagoya-u.ac.jp; Tel./Fax: +81-52-789-5484.

Academic Editor: Shusheng Pang

Received: 4 November 2014 / Accepted: 8 January 2015 / Published: 15 January 2015

\begin{abstract}
We tested a wet extraction method for lipid extraction from Euglena gracilis water slurry at $0.51 \mathrm{MPa}$ and $20{ }^{\circ} \mathrm{C}$ using liquefied dimethyl ether (DME). The yields, proximate analyses, elemental composition, and molecular weight distribution properties of the extracts from E. gracilis and the remaining residues obtained by DME extraction were compared with those of the extracts obtained by hexane Soxhlet extraction.
\end{abstract}

Keywords: dimethyl ether; Euglena gracilis; lipid extraction

\section{Introduction}

Microalgae have received significant attention as a next-generation bio-fuel resource. Compared with other energy crops, microalgae have higher photosynthetic efficiency, higher biomass production, and a faster growth rate [1]. However, being an aquatic organism, microalgae have a high water content, which causes considerable energy loss during bio-fuel production. The common procedures for algae bio-fuel production include cultivation, harvesting, dewatering, drying, oil recovery, and bio-fuel refining [2-4]. After removing water, normally cell disruption is performed to release products 
contained in the microalgae [5]. Recently, Lardon et al. conducted a life cycle assessment of algal fuel production, and indicated that drying and solvent evaporation steps consumed huge amounts of energy, resulting in a negative energy balance for algal fuel production [6,7]. Generally, algal lipids are extracted by supercritical $\mathrm{CO}_{2}$ and organic solvents such as hexane [8]. Gaseous carbon dioxide changes into the supercritical state above its critical point $\left(\mathrm{T}_{\mathrm{c}}: 31.1{ }^{\circ} \mathrm{C}, \mathrm{P}_{\mathrm{c}}: 7.3 \mathrm{MPa}\right)$, and exhibits liquid-like density and gas-like viscosity [9]. Supercritical $\mathrm{CO}_{2}$ is the most used supercritical fluid, because it is nonflammable, harmless, and inexpensive compared with other chemicals. Supercritical $\mathrm{CO}_{2}$ has a high selectivity for fractionating the high-quality components by temperature and pressure control [10]. However, drying the microalgae is a necessary pretreatment step for supercritical $\mathrm{CO}_{2}$ extraction because supercritical $\mathrm{CO}_{2}$ is a nonpolar solvent and its solubility in water is very low [11]. Moreover, special apparatuses are required to withstand the high pressure of supercritical $\mathrm{CO}_{2}$ [12]. Furthermore, lipid solubility in supercritical $\mathrm{CO}_{2}$ is lower than that in organic solvents such as hexane, because the density of supercritical $\mathrm{CO}_{2}$ is lower than that of organic solvents [13].

In a previous study, we proposed using liquefied dimethyl ether (DME) as a low-boiling-point solvent for extraction because DME can reduce the energy required for drying (dewatering) and solvent evaporation [14-16]. In addition, DME has been developed as a synthetic fuel for use in both liquid and gaseous forms. In China, DME is synthesized using small-scale coalfields of low commercial value and produced as a fuel at a cost equivalent to that of imported liquefied petroleum gas [17-19]. The boiling point of DME is $-24.8^{\circ} \mathrm{C}$ and its saturated vapor pressure at $20{ }^{\circ} \mathrm{C}$ is $0.51 \mathrm{MPa}$ [20]. As a hydrogen bond acceptor, DME forms weak hydrogen bonds, and only 7-8 wt.\% water dissolves in liquefied DME at ordinary temperature. Since the quantity of DME gas that dissolves in water is low, it can be easily separated from water by simple flash distillation at ordinary temperature [21]. Furthermore, liquefied DME has been examined as a prospective solvent in food processing because of its low toxicity [22,23]. DME differs from typical ethers such as ethyl ether since it does not form peroxides [24]. Previously, lipids were successfully extracted from seven wet cyanobacteria microalgae samples by DME, thus eliminating the need for cell drying and cell disruption and the use of a high-temperature heat source for solvent evaporation [14]. In addition to cyanobacteria, other forms of microalgae such as green algae and diatoms exist. While green algae and diatoms are eukaryotes, cyanobacteria are prokaryotes. The cell wall of cyanobacteria is mainly composed of peptidoglycan, whereas the main component of the cell wall of some green algae is cellulose and that of diatoms is silica. Since the components of the microalgae cell are different, the findings of the previous study using cyanobacteria may not be applicable to green algae or diatoms.

In this study, we tested DME extraction on wet E. gracilis, which has a simple cell structure and the ability to produce diverse valuable organic components, including lipids [25,26]. The extraction efficiency and extract properties were compared to those of the classical lipid extraction method using Soxhlet extraction with hexane. 


\section{Results and Discussion}

\subsection{Extraction Yield, Elemental Analysis, and Higher Heating Value of the Extract}

These analyses were repeated three times for each extraction. The results show the average value. Statistical analysis of the data was performed by the ANOVA analysis and the Bonferoni test $(p<0.05$ and $p<0.01)$ in order to compare different data generated in the experiments. These analyses were repeated three times for each extraction. The results show the average value. As shown in Figure 1, the best final extraction yield of $32.5 \%$ (dry basis) was achieved by passing $359.5 \mathrm{~g}$ of liquefied DME through the extractor. Furthermore, water was simultaneously removed from wet samples and the dewatering ratios are shown in Figure 1. The lipid extracted by liquefied DME was easily separated from water by a simple oil-water separation technique after the evaporation of liquefied DME. In contrast, the extraction yield obtained by hexane Soxhlet was $31.8 \%$. Therefore, the efficiency of the DME extraction compared to the hexane Soxhlet was $102.4 \%$, which demonstrates that an accurate extraction ratio, similar to that of the hexane Soxhlet, can be achieved using liquefied DME.

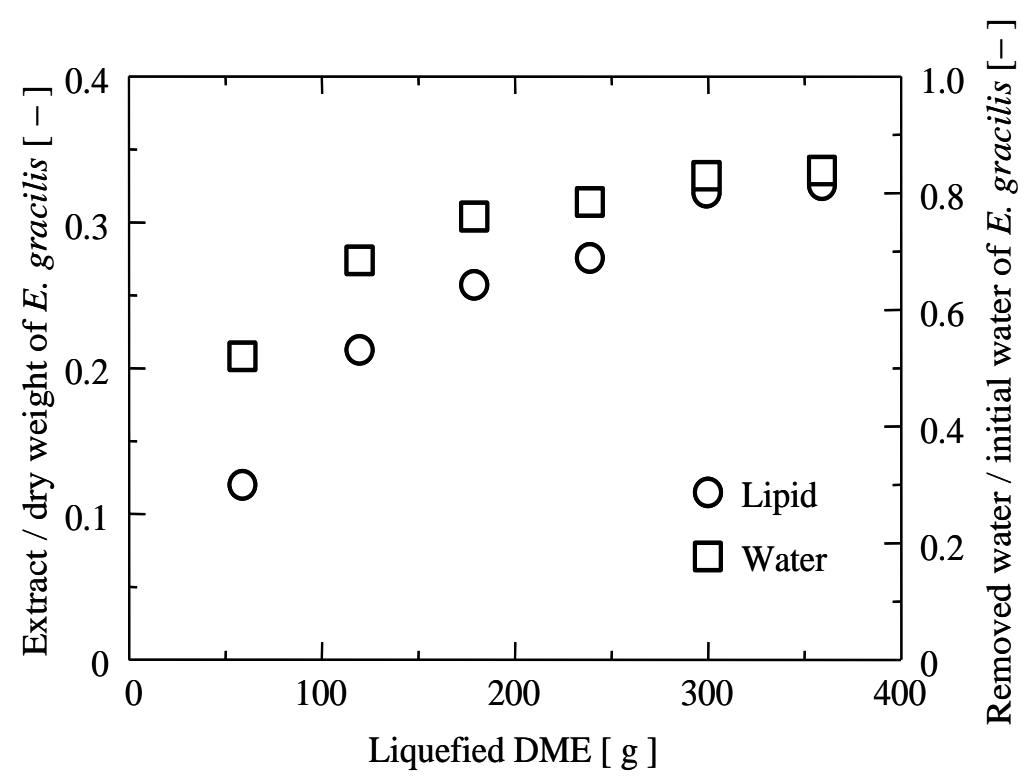

Figure 1. Extraction yields from wet E. gracilis with liquefied DME.

The upper half of Table 1 shows the proximate and higher heating value (HHV) of E. gracilis and the extracted residues and lipids. First, the ash content of E. gracilis was $6.2 \%$. The ash contents of the residue and lipid by liquefied DME extraction were $8.2 \%$ and $1.2 \%$, respectively, while those by hexane were $8.1 \%$ and $1.4 \%$, respectively. The ash concentrations in the lipids obtained by liquefied DME and hexane Soxhlet were $1.2 \%$ and $1.4 \%$, respectively, which are undesirably high and require the removal of the ash using additional refining.

The volatile matter and fixed carbon content of E. gracilis were $83.2 \%$ and $10.6 \%$, respectively (Table 1); the residue by liquefied DME were $75.2 \%$ and $16.6 \%$, respectively; and those of the residue determined by hexane were $76.2 \%$ and $15.7 \%$, respectively. Therefore, both the liquefied DME and hexane Soxhlet extraction gave slightly different results from those of E. gracilis because the volatile lipid was removed. 
Table 1. Proximate analysis, higher heating value, and elemental analysis.

\begin{tabular}{|c|c|c|c|c|c|}
\hline \multirow{2}{*}{ Analysis } & \multirow{2}{*}{ E. gracilis } & \multicolumn{2}{|c|}{ Liquefied DME } & \multicolumn{2}{|c|}{ Hexane } \\
\hline & & Residue & Lipid & Residue & Lipid \\
\hline \multicolumn{6}{|l|}{ Proximate analysis (wt.\% dry basis) } \\
\hline Ash yield & 6.2 & 8.2 & 1.2 & 8.1 & 1.4 \\
\hline Volatile matter & 83.2 & 75.2 & - & 76.2 & - \\
\hline Fixed carbon & 10.6 & 16.6 & - & 15.7 & - \\
\hline Higher heating value $(\mathrm{MJ} / \mathrm{kg})$ & 34.5 & 29.3 & 40.8 & 29.5 & 40.7 \\
\hline \multicolumn{6}{|l|}{ Main elements (wt.\% dry basis) } \\
\hline $\mathrm{C}$ & 55.5 & 45.2 & 76.5 & 46.9 & 76.3 \\
\hline $\mathrm{H}$ & 8.7 & 6.4 & 12.4 & 6.6 & 12.3 \\
\hline $\mathrm{N}$ & 6.8 & 9.8 & 2.4 & 9.5 & 2.2 \\
\hline $\mathrm{O} *$ & 21.9 & 29.2 & 7.4 & 27.7 & 7.7 \\
\hline$S$ & 0.87 & 1.23 & 0.02 & 1.21 & 0.01 \\
\hline (Non-combustible $\mathrm{S}$ ) & $<0.01$ & $<0.01$ & - & $<0.01$ & - \\
\hline \multicolumn{6}{|l|}{ Minor elements (ppm) } \\
\hline $\mathrm{Na}$ & - & - & 320 & - & 30 \\
\hline $\mathrm{K}$ & - & - & 4500 & - & 680 \\
\hline $\mathrm{Mg}$ & - & - & 1900 & - & 250 \\
\hline $\mathrm{Ca}$ & - & - & 150 & - & 170 \\
\hline $\mathrm{Al}$ & & & 3 & & $<1$ \\
\hline $\mathrm{Zn}$ & - & - & 34 & - & 10 \\
\hline $\mathrm{Fe}$ & - & - & 38 & - & 43 \\
\hline $\mathrm{P}$ & - & - & 6000 & - & 1400 \\
\hline
\end{tabular}

Note: * By calculation.

The HHV of E. gracilis was $34.5 \mathrm{MJ} \mathrm{kg}^{-1}$, while the corresponding values of the residue and lipid by liquefied DME were 29.3 and $40.8 \mathrm{MJ} \mathrm{kg}^{-1}$, respectively, and those by hexane were 29.5 and $40.7 \mathrm{MJ} \mathrm{kg}^{-1}$, respectively. For both the liquefied DME and hexane extractions, the HHVs of lipids were higher than that of E. gracilis.

The elemental composition of E. gracilis, residues, and lipids are shown in the lower half of Table 1. The lipids extracted using liquefied DME consisted mainly of $\mathrm{C}, \mathrm{H}, \mathrm{N}$, and $\mathrm{O}(76.5 \%, 12.4 \%, 2.4 \%$ and $7.4 \%$, respectively). The $\mathrm{C}$ and $\mathrm{H}$ contents of the lipids are higher than those of the raw E. gracilis; however, the $\mathrm{N}$ and $\mathrm{O}$ contents are much lower. In particular, the $\mathrm{S}$ concentrations of the extracts by both the methods are $0.02 \%$, which are significantly lower than those of the raw E. gracilis.

As described, the ash contents, volatile matter contents, fixed carbon contents, HHVs, and main element amounts of the residues and lipids by liquefied DME are almost the same as those by hexane, despite the omission of the drying and cell disruption steps in the liquefied DME extraction.

In the liquefied DME extraction, the concentrations of group IA elements $\mathrm{Na}$ and $\mathrm{K}$ in the lipid were 320 and $4500 \mathrm{ppm}$, respectively (Table 1), and the concentrations of group IIA elements $\mathrm{Mg}$ and Ca were 1900 and 150 ppm, respectively. The P concentration is also an important factor because very low levels of $\mathrm{P}$ may lead to unexpected engine deterioration [27]. The concentration of $\mathrm{P}$ that remained in the extracted lipids was $6000 \mathrm{ppm}$. This result implies that phosphatide is efficiently extracted by liquefied DME. As a reference value, the European Standard EN 14214 limits are <5.0 ppm for both 
group IA elements ( $\mathrm{Na}$ and $\mathrm{K}$ ) and group IIA elements ( $\mathrm{Ca}$ and $\mathrm{Mg}$ ), and <4 ppm for $\mathrm{P}$ [28]. The concentrations of $\mathrm{Al}, \mathrm{Zn}$, and $\mathrm{Fe}$ were 3, 34 and $38 \mathrm{ppm}$, respectively. These concentrations obtained by liquefied DME are higher than those obtained by hexane Soxhlet because liquefied DME is a more polar solvent and it is capable of extracting the nutrient medium. The analytical results presented above indicate that a subsequent refining process is required for further purification.

\subsection{Molecular Weight Distribution}

Figure 2 shows molecular weight distribution curves of the extracts determined relative to polystyrene standards. The molecular weight distribution curves obtained by liquefied DME were compared with those obtained by hexane Soxhlet extraction using gel permeation chromatography analyses using both chloroform and tetrahydrofuran (THF). Using chloroform, the average molecular weights (Mw) and the number average molecular weights $(\mathrm{Mn})$ of the nonpolar extracts were 910 and $820 \mathrm{~g} \mathrm{~mol}^{-1}$ by DME and 910 and $810 \mathrm{~g} \mathrm{~mol}^{-1}$ by hexane Soxhlet extraction, respectively. Using THF, the Mw and Mn values of the polar lipids were 820 and $720 \mathrm{~g} \mathrm{~mol}^{-1}$ for the DME extraction and 830 and $720 \mathrm{~g} \mathrm{~mol}^{-1}$ for hexane Soxhlet, respectively. The molecular weight distributions of both the nonpolar and polar lipids obtained by DME are almost the same as those obtained by hexane Soxhlet. This similarity is due to the soft cell structure of E. gracilis, because it does not have a cell wall. Therefore, all nonpolar and polar components were extracted by both solvents (liquefied DME and hexane); thus, the molecular weight distributions are independent of the solvent polarity.

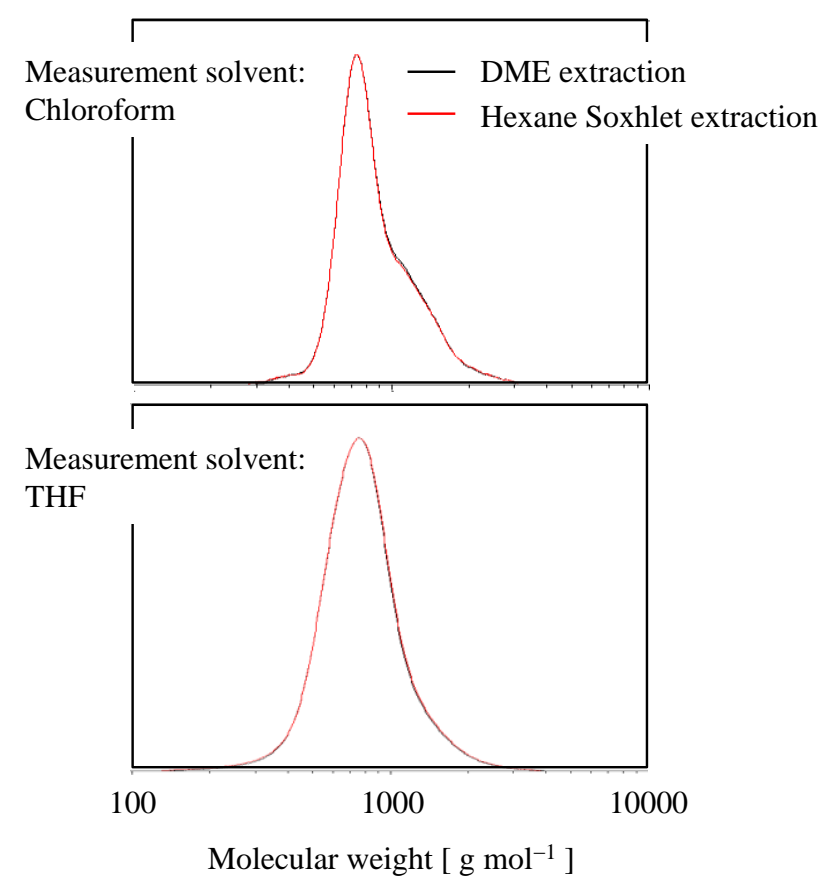

Figure 2. Molecular weight distributions of the extracts.

\subsection{Procedure Comparison of Proposed and Conventional Methods}

Recent studies of algae bio-fuel have found that the combination of hexane and a traditional extraction method such as a Soxhlet are an efficient and feasible method for the recovery of lipids from microalgae [29]. As a non-polar solvent, hexane has very good selectivity for cellular non-polar or 
neutral lipids. However, because hexane is a hydrophobic solvent, it is not able to penetrate wet algal cells to extract lipids from inside the cells. Therefore, pretreatment processes such as dewatering and drying are necessary. Several recent attempts were made to use hydrophilic organic solvents or supercritical fluid technology conceptualized as a wet extraction. However, until now none of the methods identified were both practical and economical. The procedures for the proposed DME extraction and classical hexane extraction are shown in Figure 3. In comparison to the conventional method, drying and solvent evaporation at high temperatures are not required for the DME extraction. The operational temperature shown in Figure 4 can be set arbitrarily close to the ordinary temperature and that shown as $30{ }^{\circ} \mathrm{C}$ in the figure is a typical example. The operational pressure is the saturated vapor pressure of DME. The extraction column was packed with wet microalgae collected after mechanical dewatering. The typical water content of the collected microalgae was about $90 \mathrm{wt} \%$ [14]. Water and lipids were extracted from the wet microalgae by liquefied DME, and the liquefied DME was discharged from the extraction column as a mixture with lipids and water. In order to increase the concentration of lipids in the liquefied DME, the liquefied DME was returned to the extraction column until the lipid fraction was suitably concentrated. The lipid containing liquefied DME was then heated to evaporate the DME at $30{ }^{\circ} \mathrm{C}$ in a heat exchanger by a hot heat source. As the hot heat source, sun-warmed water or waste heat generated by a small biomass electric power plant, which have commonly low electricity generation efficiency, are desirable. The $45^{\circ} \mathrm{C}$ setting of hot water shown in the figure is just an example, and it is advisable to increase the approach temperature in order to reduce the size of the heat exchanger. The evaporated DME gas at elevated temperatures and high pressures can then be condensed using a cooling source such as seawater in order to reuse the liquefied DME. The temperature of $15{ }^{\circ} \mathrm{C}$ shown for the cold heat source is just an example. The size of the heat exchanger was reduced by lowering the temperature of the cold source such as seawater. Ultimately, the temperature of the circulated DME can be determined based on the temperature of the cold heat source and the approach temperature of the heat exchanger.

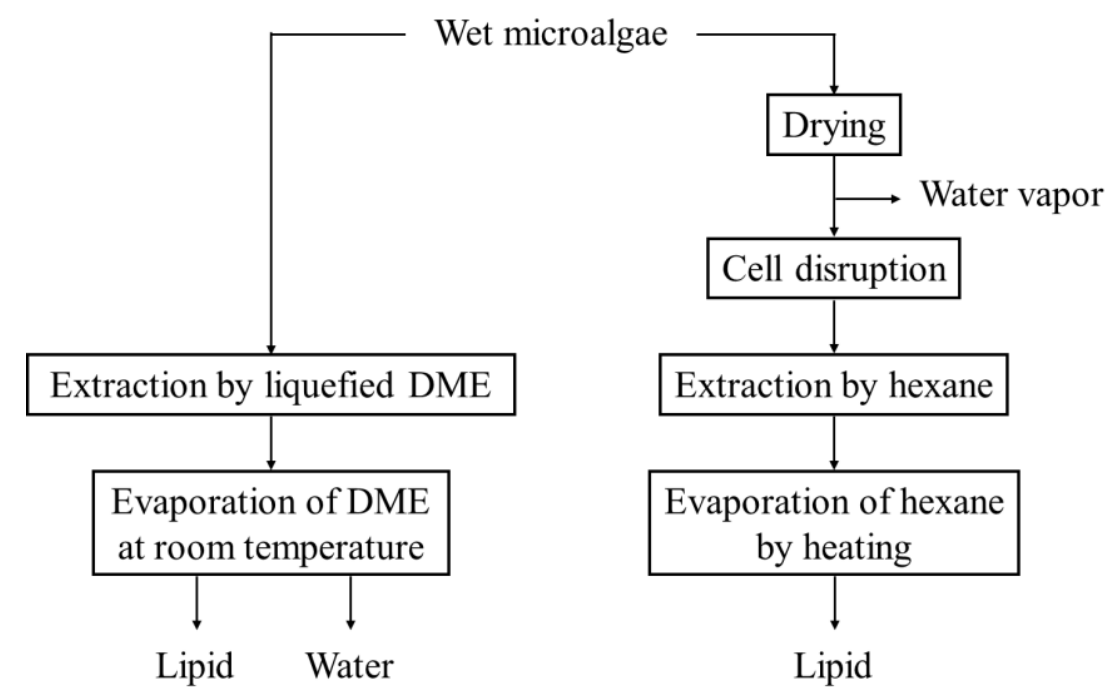

Figure 3. Comparison of the liquefied DME and typical hexane extraction procedures. 


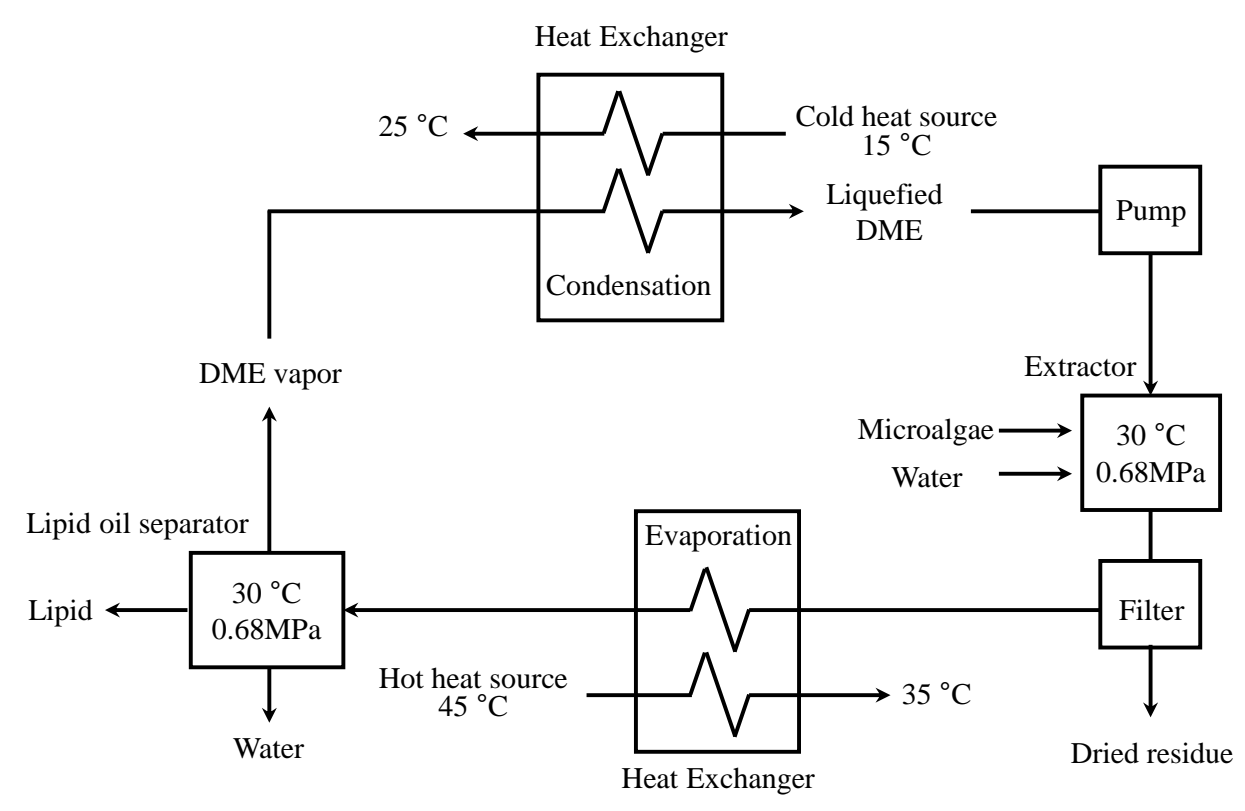

Figure 4. Process concept of energy-saving extraction by liquefied DME.

Energy consumption of the liquefied DME-sending pump can be estimated using the official basic specs of the pump, the quantity of solvent required to extract the lipids, and the amount of lipid extracted. Commercially available liquefied petroleum gas-sending pumps can be used as the liquefied DME-sending pump. The leak-proof seal of the sending pump should be coated with Teflon, which offers superior resistance to DME corrosion [30]. As an example, the official basic specs of a large-scale commercially available LPG-sending pump (Model number; E-516F2M-0810U1-E/F, Tokyo Boeki Mechanics Ltd., Tokyo, Japan) are as follows: flow rate, $800 \mathrm{~L} \mathrm{~min}^{-1}$, or $13.33 \mathrm{~L} \mathrm{~s}^{-1}$; power requirement, $15 \mathrm{~kJ} \mathrm{~s}^{-1}$; and receiving end efficiency (which is the ratio of electric energy received by the pump based on the HHV of fossil fuel consumed in a thermal power plant) in Japan, 0.369 . Therefore, $0.570 \mathrm{~g}$ (extracted lipid $=32.5 \%$ of dry weight of E. gracilis, water content of E. gracilis paste $=80.3 \%$ ) of lipids obtained were extracted by $0.544 \mathrm{~L}$ of liquefied DME $(359.5 \mathrm{~g}$, density of liquefied DME at $20{ }^{\circ} \mathrm{C}$ is $0.661 \mathrm{~g} \mathrm{~cm}^{-3}$ ).

Here, the energy consumption $(E)$ of the liquefied DME-sending pump per $\mathrm{kg}$ of lipid is calculated by the following equation:

$$
E=V / L \times W / F / R=2.96 \mathrm{MJ} \mathrm{kg}^{-1}
$$

where $V$ is the volume of the liquefied DME $(0.554 \mathrm{~L}) ; L$ is the weight of lipids extracted by liquefied DME $V(0.570 \mathrm{~g}), W$ is the energy requirement $\left(15 \mathrm{~kJ} \mathrm{~s}^{-1}\right) ; F$ is the flow rate of liquefied DME (13.33 $\mathrm{L} \mathrm{s}^{-1}$ ); and $R$ is the receiving end efficiency in Japan (0.369). Moreover, if counter flow extraction by a simulated moving bed could be employed for the DME extraction technique, the ratio of $V / L$ would be smaller than that obtained in this experiment. Therefore, energy consumption of the liquefied DME-sending pump would be much smaller than $2.96 \mathrm{MJ} \mathrm{kg}^{-1}$. This implies that the energy consumption of the liquefied DME-sending pump is clearly smaller than the HHV of the extracted lipid. 


\section{Experimental Section}

\subsection{DME and Hexane Soxhlet Extraction}

E. gracilis was provided by JX Nippon Oil \& Energy Corporation, Tokyo, Japan. It was grown in a modified Cramer-Myers medium maintained at $29 \pm 3{ }^{\circ} \mathrm{C}$. The $\mathrm{pH}$ was maintained in the range $2-4.5$ in order to prevent contamination through the supply of $\mathrm{CO}_{2}$. The depth of the culture solution was maintained at about $0.30 \mathrm{~m}$ to maintain efficient photosynthesis. For extraction test pretreatment, the E. gracilis cells were roughly dewatered by suction filtration. The water content of the E. gracilis paste was $80.3 \%$, as determined by continual drying at $107{ }^{\circ} \mathrm{C}$ to constant weight. Wet E. gracilis was then used in the DME extraction. A liquefied DME supplier (volume: $100 \mathrm{~cm}^{3}$; TVS-1-100, Taiatsu Techno Corp., Saitama, Japan), an extraction column (inner diameter: 11.6 mm, HPG-10-5, Taiatsu Techno Corp.), and a storage tank for the extract (HPG-96-3, Taiatsu Techno Corp.) were connected in series, as shown in Figure 5. Based on an average of three tests, $8.91 \mathrm{~g}$ of wet E. gracilis was placed in the lower half of an extractor, and glass beads (0.71-0.99 mm diameter) were placed in the upper half of the extractor. The extractor was pressure-resistant glass coated with polycarbonate, and was positioned in a water tank to maintain the temperature at $20{ }^{\circ} \mathrm{C}$. Liquefied DME was supplied to the extractor by using 0.7 MPa of nitrogen gas and the flow rate was adjusted by a pressure depression valve. At a predetermined temperature and pressure, liquefied DME was passed through the extractor at a flow rate of $10 \pm 1 \mathrm{~cm}^{3} \mathrm{~min}^{-1}$.

For the Soxhlet extraction with hexane, heat-dried E. gracilis were disrupted for $5 \mathrm{~min}$ at 10,000 rpm in hexane using a homogenizer equipped with a 10-mm outside diameter sawtooth generator probe (Dremel 300 Series; Robert Bosch Tool Corp., Mount Prospect, IL, USA). The time and temperature employed for the hexane Soxhlet extraction were $18 \mathrm{~h}$ and $69^{\circ} \mathrm{C}$, respectively.

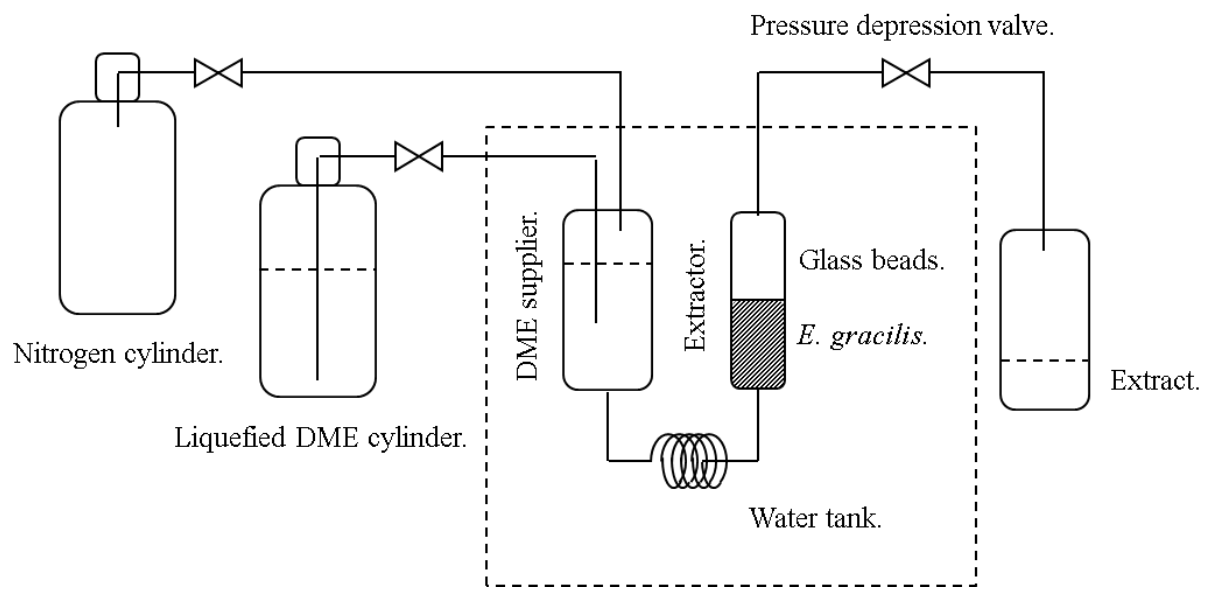

Figure 5. Schematic diagram of the DME extraction apparatus.

\subsection{Compositional Analyses}

The ash contents, higher heating value, and main elements amounts were analyzed for raw E. gracilis, residues, and lipids obtained by liquefied DME and hexane extractions.

Volatile matter and fixed carbon contents, which are typically analyzed for coal, were analyzed for the original E. gracilis and E. gracilis residue. Minor elemental contents, which are typically analyzed 
for crude oil, were analyzed only for lipids. E. gracilis, residues, and lipids were pretreated for these analyses by continually drying at $107^{\circ} \mathrm{C}$ to constant weight.

The ash contents were determined according to the analytical method of the Japanese Industrial Standard (JIS) Z 7302-4:1999, the volatile matter contents and fixed carbon contents were determined according to the analytical method of JIS M 8812:2004 7, and the higher heating values were determined according to the analytical method of JIS Z 7302-2:1999.

The carbon, hydrogen, and nitrogen contents were determined according to the analytical method of JIS Z 7302-8:2002. The oxygen contents were calculated by difference. The sulfur content was determined according to the analytical method of JIS Z 7302-7:2002 7.1b.

The concentrations of minor elements such as $\mathrm{Na}, \mathrm{K}, \mathrm{Ca}, \mathrm{Mg}, \mathrm{Ca}, \mathrm{Al}, \mathrm{Zn}$, and Fe were determined by atomic absorption spectrometry (Z-2000; Hitachi High-Technologies Corp., Tokyo, Japan) according to the Japanese industrial standard method of JIS K 0102:2008 48.2, JIS K 0102:2008 49.2, JIS K 0102:2008 50.2, and JIS K 0102:2008 51.2, which correspond to ISO 14911:1998. Phosphorus concentrations were determined by potassium peroxodisulfate digestion molybdenum blue absorption spectroscopy (U-2001; Hitachi High-Technologies Corp.) according to the analytical methods of JIS K 0102:2008 46.3.2, which corresponds to ISO 6878:2004.

The molecular weight distributions of the lipids obtained by liquefied DME and hexane were determined by gel permeation chromatography performed at $40{ }^{\circ} \mathrm{C}$ by diluting the extracts in either chloroform or THF. Chloroform is a suitable solvent for the nonpolar components of the lipids. THF is a suitable solvent for polar components. For chloroform, one Shodex K-800D and two K-805L columns (Showa Denko K.K., Tokyo, Japan) were employed. For THF, one Shodex KF-G, two KF-805L, and KF-800D columns (Showa Denko K.K.) were used. These properties were compared with the results of the hexane Soxhlet.

\section{Conclusions}

We have demonstrated that liquefied DME extraction is suitable for wet E. gracilis. The lipid extraction yield, proximate analysis results, $\mathrm{C}, \mathrm{H}, \mathrm{N}, \mathrm{O}$, and $\mathrm{S}$ compositions, and molecular weight distribution of the lipid obtained by liquefied DME were identical to those obtained by hexane. In contrast to conventional Soxhlet extraction, this method does not require drying, cell disruption, or solvent evaporation at high temperatures. Minor element concentrations in the lipid by liquefied DME were higher than those obtained by hexane because of weak hydrogen bonds of liquefied DME, which indicates another refining process is required for further purification.

\section{Acknowledgments}

A part of this research was supported by the Industrial Technology Research Grant Program (Project ID: 09B40009c, Hideki Kanda) from the New Energy and Industrial Technology Development Organization of Japan and a grant from the Precursory Research for Embryonic Science and Technology Program (PRESTO; Hideki Kanda) of the Japan Science and Technology Agency. 


\section{Author Contributions}

Hideki Kanda contributed to the overall idea, planning, financing, and writing of the manuscript. Peng Li contributed to the experiment, analysis, interpretation, and writing of the manuscript. The research direction was provided by Motonobu Goto and Hisao Makino.

\section{Conflicts of Interest}

The authors declare no conflict of interest.

\section{References}

1. Chisti, Y. Biodiesel from microalgae. Biotechnol. Adv. 2007, 25, 294-306.

2. Sander, K.; Murthy, G.S. Life cycle analysis of algae biodiesel. Int. J. Life Cycle Assess. 2010, 15, 704-714.

3. Kadam, K.L. Environmental implications of power generation via coal-microalgae cofiring. Energy 2002, 27, 905-922.

4. Stephenson, A.L.; Kazamia, E.; Dennis, J.S.; Howe, C.J.; Scott, S.A.; Smith, A.G. Life-cycle assessment of potential algal biodiesel production in the United Kingdom: A comparison of raceways and air-lift tubular bioreactors. Energy Fuels 2010, 24, 4062-4077.

5. Halim, R.; Rupasinghe, T.; Tull, D.L.; Webley, P.A. Mechanical cell disruption for lipid extraction from microalgal biomass. Bioresour. Technol. 2013, 140, 53-63.

6. Reijnders, L. Do biofuels from microalgae beat biofuels from terrestrial plants? Trends Biotechnol. 2008, 26, 349-350.

7. Lardon, L.; Hélias, A.; Sialve, B.; Steyer, J.-P.; Bernard, O. Life-cycle assessment of biodiesel production from microalgae. Environ. Sci. Technol. 2009, 43, 6475-6481.

8. Andrich, G.; Zinnai, A.; Nesti, U.; Venturi, F.; Fiorentini, R. Supercritical fluid extraction of oil from microalga Spirulina (Arthrospira) platensis. Acta Alimentaria 2006, 35, 195-203.

9. Sahena, F.; Zaidul, I.S.M.; Jinap, S.; Karim, A.A.; Abbas, K.A.; Norulaini, N.A.N.; Omar, A.K.M. Application of supercritical $\mathrm{CO}_{2}$ in lipid extraction-A review. J. Food Eng. 2009, 95, 240-253.

10. Sato, M.; Goto, M.; Hirose, T. Fractional extraction with supercritical carbon dioxide for the removal of terpenes from citrus oil. Ind. Eng. Chem. Res. 1995, 34, 3941-3946.

11. Durante, M.; Lenucci, M.S.; D’Amico, L.; Piro, G.; Mita, G. Effect of drying and co-matrix addition on the yield and quality of supercritical $\mathrm{CO}_{2}$ extracted pumpkin (Cucurbita moschata Duch.) oil. Food Chem. 2014, 148, 314-320.

12. Machmudah, S.; Kawahito, Y.; Sasaki, M.; Goto, M. Supercritical $\mathrm{CO}_{2}$ extraction of rosehip seed oil: Fatty acids composition and process optimization. J. Supercrit. Fluids 2007, 41, 421-428.

13. Valderrama, J.O.; Perrut, M.; Majewski, W. Extraction of astaxantine and phycocyanine from microalgae with supercritical carbon dioxide. J. Chem. Eng. Data 2003, 48, 827-830.

14. Kanda, H.; Li, P. Simple extraction method of green crude from natural blue-green microalgae by dimethyl ether. Fuel 2011, 90, 1264-1266. 
15. Makino, H.; Kanda, H.; Morita, M.; Kinura, T.; Yoshikoshi, A. Yuukibutsu no tyuusyutsu houhou, yuukibutsu no seizou houhou, yuukibutsu tyuusyutsu souchi kumitatetai, sitsujyunzairyou no syorihouhou. JP 5328547, 31 July 2009. (In Japanese)

16. Catchpole, O.J.; Grey, J.B.; Mackenzie, A.D.; Tallon, S.J. Energy efficient method and apparatus for the extraction of biomolecules from dilute aqueous solution. WO 2014039638, 5 September 2012.

17. Fast, G.; Kuhn, D.; Class, A.G.; Maas, U. Auto-ignition during in stationary jet evolution of dimethyl ether (DME) in a high-pressure atmosphere. Combust. Flame 2009, 156, 200-213.

18. Lee, M.C.; Seo, S.B.; Chung, J.H.; Joo, Y.J.; Ahn, D.H. Industrial gas turbine combustion performance test of DME to use as an alternative fuel for power generation. Fuel 2009, 88, 657-662.

19. Cho, W.; Song, T.; Mitsos, A.; McKinnon, J.T.; Ko, G.H.; Tolsma, J.E.; Denholm, D.; Park, T. Optimal design and operation of a natural gas tri-reforming reactor for DME synthesis. Catal. Today 2009, 139, 261-267.

20. Wu, J.; Zhou, Y.; Lemmon, E.W. An equation of state for the thermodynamic properties of dimethyl ether. Phys. Chem. Ref. Data 2011, 40, 023104:1-023104:15.

21. Holldorff, H.; Knapp, H. Binary vapor-liquid-liquid equilibrium of dimethyl ether-water and mutual solubilities of methyl chloride and water-Experimental results and data reduction. Fluid Phase Equilib. 1988, 44, 195-209.

22. Scientific opinion of the panel on food contact materials, enzymes, flavourings and processing aids (CEF) on dimethyl ether as an extraction solvent. EFSA J. 2009, 984, 1-13.

23. Varlet, V.; Smith, F.; Augsburger, M. New trends in the kitchen: Propellants assessment of edible food aerosol sprays used on food. Food Chem. 2014, 142, 311-317.

24. Naito, M.; Radcliffe, C.; Wada, Y.; Hoshino, T.; Liu, X.; Arai, M.; Tamura, M. A comparative study on the autoxidation of dimethyl ether (DME) comparison with diethyl ether (DEE) and diisopropyl ether (DIPE). J. Loss Prevent. Proc. 2005, 18, 469-473.

25. Takeyama, H.; Kanamaru, A.; Yoshino, Y.; Kakuta, H.; Kawamura, Y.; Matsunaga, T. Production of antioxidant vitamins, $\beta$-carotene, vitamin $\mathrm{C}$, and vitamin E, by two-step culture of Euglena gracilis Z. Biotechnol. Bioeng. 1997, 53, 185-190.

26. Rodríguez-Zavala, J.S.; Ortiz-Cruz, M.A.; Mendoza-Hernández, G.; Moreno-Sánchez, R. Increased synthesis of $\alpha$-tocopherol, paramylon and tyrosine by Euglena gracilis under conditions of high biomass production. J. Appl. Microbiol. 2010, 109, 2160-2172.

27. Mata, T.M.; Martins, A.A.; Caetano, N.S. Microalgae for biodiesel production and other applications-A review. Renew. Sust. Energy Rev. 2010, 14, 217-232.

28. Rosenberg, A. A comparison of lipid patterns in photosynthesizing and nonphotosynthesizing cells of Euglena Gracilis. Biochemistry 1963, 2, 1148-1154.

29. Mercer, P.; Armenta, R.E. Developments in oil extraction from microalgae. Eur. J. Lipid Sci. Technol. 2011, 113, 539-547.

30. Kanda, H.; Makino, H. Energy-efficient coal dewatering using liquefied dimethyl ether. Fuel 2010, 89, 2104-2109.

(C) 2015 by the authors; licensee MDPI, Basel, Switzerland. This article is an open access article distributed under the terms and conditions of the Creative Commons Attribution license (http://creativecommons.org/licenses/by/4.0/). 